Original Article

\title{
Death caused by covid-19 in top ten countries in Asia affected by covid-19 pandemic with special reference to Pakistan
}

\author{
Morte causada por covid-19 nos dez principais países da Ásia afetados pela pandemia \\ de covid-19, com referência especial ao Paquistão
}

\author{
W. Khan ${ }^{\text {** }}$ (1), A.A. Khanª J. Khan ${ }^{\mathrm{b}}$, N. Khatoon, S. Arshadc and P. De los Ríos Escalanted,e (1) \\ aUniversity of Malakand, Department of Zoology, Lower Dir, Pakistan \\ bUniversity of Malakand, Department of Pharmacy, Lower Dir, Pakistan \\ 'University of Karachi, Department of Zoology, Karachi, Pakistan \\ ¿Universidad Católica de Temuco, Facultad de Recursos Naturales, Departamento de Ciencias Biológicas y Químicas, Temuco, Chile \\ eNúcleo de Estudios Ambientales UC Temuco, Casilla, Temuco, Chile
}

\begin{abstract}
The COVID-19 is a contagious viral disease, was first emerged in Wuhan, China in December 2019 and became the whole world on alert. The mortality rate in top most countries in Asia with special reference to Pakistan has been focused. Since February 26 to September 2020 the total confirmed cases and mortality rate was measured through Wikipedia and the notable journals. Iran is the only country having highest number of deaths (5.73\%) followed by Indonesia (3.77\%) while Saudi Arabia shows the lowest number of deaths as $1.39 \%$. In Pakistan the first case was confirmed in $26^{\text {th }}$ February, 2020. The nCov-19 has closely related to severe acute respiratory syndrome (SARS) hence SARS COV-2 was named. This virus is responsible for more than 33.9 million deaths in over all the world as of $20^{\text {th }}$ September, 2020. The number of new cases is increasing time to time. Sindh province of Pakistan has reported the highest number of cases till September, 20, 2020 as compared to other parts of the country and has the highest number of death followed by Khyber Pakhtunkhwa. Because of the person to person contact the disease is spreading rapidly. The individuals who has already infected with other diseases like cancer or diabetic etc. are vulnerable. The nCOV-19 is the most contagious due to its mode of transmission. There is still no vaccine is available for the treatment of disease caused by nCoV-2019. It is therefore the only option to control this pandemic is to adopt effective preventive measures.
\end{abstract}

Keywords: COVID-19, pandemic, SARS-2, outbreak, zoonosis.

\section{Resumo}

A covid-19 é uma doença viral contagiosa, que surgiu pela primeira vez em Wuhan, China, em dezembro de 2019, e deixou o mundo todo em alerta. A taxa de mortalidade na maioria dos principais países da Ásia, com referência especial ao Paquistão, foi enfocada. De 26 de fevereiro a setembro de 2020, o total de casos confirmados e a taxa de mortalidade foram medidos por meio da Wikipedia e de periódicos notáveis. O Irã é o único país com maior número de mortes (5,73\%), seguido pela Indonésia (3,77\%), enquanto a Arábia Saudita mostra o menor número de mortes, 1,39\%. No Paquistão, o primeiro caso foi confirmado em 26 de fevereiro de 2020 . O nCov-19 está intimamente relacionado à síndrome respiratória aguda grave (SARS), daí o nome SARS COV-2. Esse vírus é responsável por mais de 33,9 milhões de mortes em todo o mundo em 20 de setembro de 2020. O número de novos casos está aumentando de tempos em tempos. A província de Sindh, no Paquistão, registrou o maior número de casos até 20 de setembro de 2020, em comparação com outras partes do país, e tem o maior número de mortes, seguida por Khyber Pakhtunkhwa. Por causa do contato pessoa a pessoa, a doença está se espalhando rapidamente. Indivíduos que já foram diagnosticados com outras doenças, como câncer ou diabetes, etc. são mais vulneráveis. O nCOV-19 é o mais contagioso devido ao seu modo de transmissão. Ainda não há vacina disponível para o tratamento da doença causada pelo nCoV-2019. Portanto, a única opção para controlar essa pandemia é a adoção de medidas preventivas eficazes.

Palavras-chave: COVID-19, pandemia, SARS-2, surto, zoonose.

\section{Introduction}

The government of China reported nCOV-19 as a causative agent of the infection in lower respiratory

tract for the first time which was named as novel coronavirus pneumonia (NCP). The WHO recommended

*e-mail: walikhan.pk@gmail.com

Received: February 2, 2021 - Accepted: April 14, 2021

This is an Open Access article distributed under the terms of the Creative Commons Attribution License, which permits unrestricted use, distribution, and reproduction in any medium, provided the original work is properly cited. 
it as COVID-19 however after a successful trial by the International Committee on Taxonomy of Viruses, it was renamed as SARS-CoV-2 (Yuen et al., 2020).

This virus is highly contagious and causes the disease with symptoms like fever, dry cough, fatigue, myalgia, and dyspnea (Chen et al., 2020). The COVID-19 pandemic spreaded very rapidly and by October $1^{\text {st }}, 2020$, the virus had spread all over the world, resulting 33.9 million cases and 1.01 million deaths (Lau et al., 2021). Due to the high rate of transmission, on January 30, 2020 the WHO declared it is a public health emergency in global concern and communicated to all the countries to come out for the battle against the disease (WHO, 2020).

Person to person transmission of SARS-CoV-2 was first evidenced by scientists from Hong Kong University and was comprised in the following stages: this disease can spread upto $83 \%$ of the population; the clinical manifestations was from mild to moderate; asymptomatic virus shedding raises the possibility for transmission from asymptomatic carriers to others and the presentation of diarrhea suggests the possibility for gastrointestinal involvement and fecal-oral transmission. This study is more helpful for the control and management of COVID-19 (Chan et al., 2020).

Karachi, a capital city in Sindh Province Pakistan hit by the COVID-19 epidemic in $26^{\text {th }}$ February, 2020 for the first time. Some protective measures were adopted to control the COVID-19 transmission in Sindh and other provinces of Pakistan, including the suspension of public transportation, the closing of public places, families' management at home, isolation, care for infected people and monitoring suspected cases. Until the Mid of March, government of Pakistan locked down the whole country and imposed to stay at home to avoid contacting with others. The battle against COVID-19 is now at its end in Pakistan and the rest of the world while China has overcome.

Studies on nCoV-19 (SARS-CoV-2) have been published in the past few weeks to report on clinical characteristics (Wang et al., 2020), genome sequencing (Lu et al., 2020), possible intermediate host (Lam et al., 2020), the evolutionary reservoir (Zhou et al., 2020). It is the time to educate the people on transmission pattern, risk factors and management of COVID-19. To facilitate outbreak management of COVID-19 in Pakistan, there is an urgent need to understand the public awareness of COVID-19 at this critical moment. Current study addresses the ongoing situation of COVID-19 during the rapid rise period outbreak in Pakistan.

\section{Study Design}

The most interesting articles have been published on different aspects of nCOVID-19 in various reputed journals internationally. Present study was mapped in the helpline of the related review of literature. For the collection of the information, most of the data was collected via published articles. The Wikipedia, the free encyclopedia was searched for 2020 COVID-19 pandemic in Pakistan on regular intervals. Excel graphs were designed for the presentation of the data. In calculating the percent prevalence of the cases, the number of cases reported, number of deaths, number of recovered cases and the number of active cases were multiplied by 100 and divided by total number of laboratory confirmed cases.

\section{Results}

Table 1 demonstrates the pattern of infection caused by COVID-19 outbreak pandemic in Pakistan since $26^{\text {th }}$ February to $20^{\text {th }}$ September. A total of 301481 cases were reported including 131880 Sindh, 97679 Punjab, 36942 KPK, 15901 Islamabad, 3196 G.Biltistan, 13483 Baluchistan and 2400 Azad Kashmir respectively. In terms of actives cases $1.88 \%(n=5673)$ were reported overall including $10.4 \%(n=333)$

G.Biltistan followed by 7.43\%(n=1002) Baluchistan, 5.12\%(n=123) Azad Kashmir, 2.49\%(n=396) Islamabad, 2.14\%(n=791) KPK, 1.53\%(n=2019) Sindh, 1.03\%(n=1009) respectively. in current study $96 \%(n=289429)$ lives have been recovered including $96.9 \%(n=94453)$ in Punjab, 96.6\%( $n=127418)$ Sindh, 96.3\%( $n=15327)$ Islamabad, 94.4\%(n=34894) KPK, 92.1\%(n=2212) Azad Kashmir,91.4\%( $n=12336)$ Baluchistan, 87.2\%( $n=2789)$ G-Biltistan. Regarding deaths $2.11 \%(n=6379)$ including 3.40\%(1257) KPK, 2.70\%(=65) Azad Kashmir, 2.31\%(n=74) G.Biltistan, 2.26\%(n=2217) Punjab, 1.85\%( $n=2443)$ Sindh, $1.11 \%(n=178)$ Islamabad and $1.07 \%(145)$ Baluchistan were reported.

Iran is the only country In Asia having the highest number of deaths (5.73\%) followed by Indonesia (3.77\%) while Saudi Arabia showed the lowest number of deaths $1.39 \%$ (Table 2 ).

Table 1. Pattern of infection caused by COVID-19 outbreak pandemic in Pakistan (26 $6^{\text {th }}$ February to $20^{\text {th }}$ September, 2020).

\begin{tabular}{crrrrrrrr}
\hline \multirow{2}{*}{$\begin{array}{c}\text { Pattern of } \\
\text { cases }\end{array}$} & $\begin{array}{c}\text { AJK } \\
\text { N(\%) }\end{array}$ & Baluchistan & $\begin{array}{c}\text { Gilgit } \\
\text { Baltsitan }\end{array}$ & Islamabad & KPK & Punjab & Sindh & Total \\
\hline Total cases & 2400 & 13483 & 3196 & 15901 & 36942 & 97679 & 131880 & 301481 \\
Active cases & $123(5.12)$ & $1002(7.43)$ & $333(10.4)$ & $396(2.49)$ & $791(2.14)$ & $1009(1.03)$ & $2019(1.53)$ & $5673(1.88)$ \\
Recoveries & $2212(92.1)$ & $12336(91.4)$ & $2789(87.2)$ & $15327(96.3)$ & $34894(94.4)$ & $94453(96.9)$ & $127418(96.6)$ & $289429(96.0)$ \\
Deaths & $65(2.70)$ & $145(1.07)$ & $74(2.31)$ & $178(1.11)$ & $1257(3.40)$ & $2217(2.26)$ & $2443(1.85)$ & $6379(2.11)$ \\
\hline
\end{tabular}


Table 2. Top 10 countries in Asia affected by COVID-19 pandemic.

\begin{tabular}{ccccc}
\hline S.No. & Country & Cases & Death & Percent prevalence \\
\hline 1$)$ & India & $5,992,532$ & 94,503 & 1.57 \\
$2)$ & Russia & $1,146,273$ & 20,239 & 1.76 \\
$3)$ & Iran & 443,086 & 25,394 & 5.73 \\
$4)$ & Bangladesh & 359,148 & 5,161 & 1.43 \\
$5)$ & Iraq & 345,969 & 8,935 & 2.58 \\
$6)$ & Saudi Arabia & 332790 & 4655 & 1.39 \\
$7)$ & Turkey & 312966 & 4655 & 1.48 \\
$8)$ & Pakistan & 310275 & 6457 & 2.08 \\
$9)$ & Philippines & 304226 & 5344 & 1.75 \\
$10)$ & Indonesia & 275213 & 10386 & 3.77 \\
\hline
\end{tabular}

\section{Discussion}

The outbreak of the novel coronavirus disease, (nCOVID-19) formally designated as severe acute respiratory syndrome-related coronavirus SARS-CoV-2. This disease represents a pandemic threat to global public health (Gorbalenya et al., 2020; Kupferschmidt and Cohen, 2020). The outbreak initiated from Wuhan, China and spreaded to all over the world resulting 33.9 million laboratory confirmed cases and 1.01 million deaths (Coronavirus Update (Lau et al., 2021) as of September, 20, 2020. In the month of September the highest cases 133947 were reported in Sindh followed by Punjab 98428, KPK, 37357, Isalamabad 15649, Baluchistan 12879, G.Biltistan 2903, Azad Kashmir 2299.

At present, a total of 306,304 cases were reported in Pakistan including Sindh province of Pakistan is on the top to record 133947 laboratory confirmed cases and Punjab with 98428 on second number while the least number of cases were recorded in Azad Kashmir 2299. Furthermore, millions of people's lives have been affected as a result of mandatory isolations/ quarantines. The current effect of the COVID-19 outbreak could potentially bring major challenges to health system of the world and may affect the global economy if the spread was not effectively controlled (Gorbalenya et al., 2020; Kupferschmidt and Cohen, 2020).

The outbreak of COVID-19 has drawn major global attention. Scientists and physicians in the world are attempting to understand this new emergent disease, its epidemiology, making the efforts to expose possible treatment, discover effective therapeutic agents, and to develop vaccines.

According to Rothan and Byrareddy (2020), the recovery period of COVID-19 infection is 6-14 days. In China, about $80 \%$ of deaths were in over 60 years in age, and $75 \%$ comorbidities including cardiovascular diseases and diabetes (WHO, 2020).

It is important to note that the real number of people infected due to mild or asymptomatic condition are still unknown. A recent modelling estimated the population attack rate to be between 0.75 per 100,000 to 15.8 per 100,000 analysing rates down to prefecture level in China
(Yang et al., 2020). Any determination of incidence may likely to be an underestimate, since it will not include mild and asymptomatic cases. Accuracy of such estimates may depend on the development of sensitive and specific serologic tests.

Disease controlling professionals, practicing physicians and scientists are disconnected in the fight against SARSCoV-2 and COVID-19. In addition, important decisions were not made by experts in the field. Hopefully, these issues may be dealt with swiftly and decisively during and after the outbreak. There are two possibilities that this outbreak may unfold, If SARS-CoV-2 is not eliminated from humans through quarantine and other measures, it can still be eradicated by vaccination. If it attenuates to become another community-acquired human coronavirus causing mild respiratory tract disease resembling the other four human coronaviruses associated with common cold, it will not be a disaster either. Before SARS-CoV-2 attenuates further to a much less virulent form, early diagnosis and improved treatment of severe cases hold the key to reduce mortality. We should remain on one page against this. Redoubling our research efforts on SARS-CoV-2 and COVID-19 will solidify the scientific basis on which important decisions are made.

Crucially, doctors and researchers around the world are tackling the problem with urgency, Henao Restrepo says. "This is a crisis like no other and we will have to work together," she says. "That is the only way perhaps we are going to find a solution (Kupferschmidt and Cohen, 2020).

This is a time that we would have to follow advice from the government, the WHO and the scientific community. Ensuring the health safety and wellbeing are important steps for the society and this is only possible to ensure the call "stay home and save the nation" should reached to each individual in the globe.

\section{Acknowledgements}

Authors acknowledge Dr. Noor UN Nisa for her critical evaluation of the manuscript during formatting. However no financial source was available in the completion of this study. 


\section{References}

CHAN, J.F.W., YUAN, S., KOK, K.H., TO, K.K.W., CHU, H., YANG, J., XING, F., LIU, J., YIP, C.C.Y., POON, R.W.S., TSOI, H.W., LO, S.K., CHAN, K.H., POON, V.K., CHAN, W.M., IP, J.D., CAI, J.P., CHENG, V.C., CHEN, H., HUI, C.K. and YUEN, K.Y., 2020. A familial cluster of pneumonia associated with the 2019 novel coronavirus indicating person-to-person transmission: a study of a family cluster. Lancet, vol. 395, no. 10223, pp. 514-523. http://dx.doi. org/10.1016/S0140-6736(20)30154-9. PMid:31986261.

CHEN, N., ZHOU, M., DONG, X., QU, J., GONG, F., HAN, Y., QIU, Y., WANG, J., LIU, Y., WEI, Y., XIA, J., YU, T., ZHANG, X. and ZHANG, L., 2020. Epidemiological and clinical characteristics of 99 cases of 2019 novel coronavirus pneumonia in Wuhan, China: a descriptive study. Lancet, vol. 395, no. 10223, pp. 507-513. http:// dx.doi.org/10.1016/S0140-6736(20)30211-7. PMid:32007143.

GORBALENYA, A.E., BAKER, S.C., BARIC, R., GROOT, R.J.D., DROSTEN, C., GULYAEVA, A.A. and PENZAR, D., 2020. The species Severe acute respiratory syndrome-related coronavirus: classifying 2019-nCoV and naming itSARS-CoV-2. Nature Microbiology, vol. 5, no. 4, pp. 536544. http://dx.doi.org/10.1038/s41564-020-0695-z PMid:32123347.

KUPFERSCHMIDT, K. and COHEN, J., 2020. Race to find COVID-19 treatments accelerates WHO launches megatrial to test repurposed drugs and experimental drug candidates. Science, vol. 367, no. 6485, pp. 1412-1413. http://dx.doi.org/10.1126/ science.367.6485.1412. PMid:32217705.

LAM, T.T., JIA, N., ZHANG, Y.W., SHUM, M.H., JIANG, J.F., ZHU, H.C., TONG, Y.G., SHI, Y.X., NI, X.B., LIAO, Y.S., LI, W.J., JIANG, B.G., WEI, W., YUAN, T.T., ZHENG, K., CUI, X.M., LI, J., PEI, G.Q., QIANG, X., CHEUNG, W.Y., LI, L.F., SUN, F.F., QIN, S., HUANG, J.C., LEUNG, G.M., HOLMES, E.C., HU, Y.L., GUAN, Y. and CAO, W.C., 2020. Identifcation of 2019-nCoV related coronaviruses in Malayan pangolins in southern China. Nature, vol. 583, pp. 282-285. http://dx.doi.org/10.1038/s41586-020-2169-0. PMid:32218527.

LAU, H., KHOSRAWIPOUR, T., KOCBACH, P., ICHII, H., BANIA, J. and KHOSRAWIPOUR, V., 2021. Evaluating the massive underreporting and undertesting of COVID-19 cases in multiple global epicenters. Pulmonology, vol. 27, no. 2, pp. 110-115. http:// dx.doi.org/10.1016/j.pulmoe.2020.05.015. PMid:32540223.

LU, R., ZHAO, X., LI, J., NIU, P., YANG, B., WU, H., WANG, W., SONG, H., HUANG, B., ZHU, N., BI, Y., MA, X., ZHAN, F., WANG, L., HU, T., ZHOU, H., HU, Z., ZHOU, W., ZHAO, L., CHEN, J., MENG, Y.,
WANG, J., LIN, Y., YUAN, J., XIE, Z., MA, J., LIU, W.J., WANG, D., XU, W., HOLMES, E.C., GAO, G.F., WU, G., CHEN, W., SHI, W. and TAN, W., 2020. Genomic characterisation and epidemiology of 2019 novel coronavirus: implications for virus origins and receptor binding. Lancet, vol.395, no. 10224, pp. 565-574. http:// dx.doi.org/10.1016/S0140-6736(20)30251-8. PMid:32007145.

ROTHAN, H.A. and BYRAREDDY, S.N., 2020. The epidemiology and pathogenesis of coronavirus disease (COVID-19) outbreak. Journal of Autoimmunity, vol. 109, pp. 102433. http://dx.doi. org/10.1016/j.jaut.2020.102433. PMid:32113704.

WANG, D., HU, B., HU, C., ZHU, F., LIU, X., ZHANG, J., WANG, B., XIANG, H., CHENG, Z., XIONG, Y., ZHAO, Y., LI, Y., WANG, X. and PENG, Z., 2020. Clinical characteristics of 138 hospitalized patients with 2019 novel coronavirus-infected pneumonia in Wuhan, China. Journal of the American Medical Association, vol. 323, no. 11, pp. 1061-1069. http://dx.doi.org/10.1001/jama.2020.1585. PMid:32031570.

WORLD HEALTH ORGANIZATION - WHO, 2020 [viewed 16 February 2020]. 2019-nCoV outbreak is an emergency of international concern [online]. Available from: http://www.euro.who.int/en/ health-topics/emergencies/pages/news/new s/2020/01/2019ncov-outbreak-is-an-emergency-of-international-concern

YANG, Y., LU, Q.-B., LIU, M.-J., WANG, Y.-X., ZHANG, A.-R., JALALI, N., DEAN, N.E., LONGINI, I., HALLORAN, M.E., XU, B., ZHANG, X.-A., WANG, L.-P., LIU, W. and FANG, L.-Q., 2020. Epidemiological and clinical features of the 2019 novel coronavirus outbreak in China. medRxiv. In press. http://dx.doi.org/10.1101/2020.0 2.10.20021675.

YUEN, K.S., YE, Z.W., FUNG, S.Y., CHAN, C.P. and JIN, D.Y., 2020. SARS-CoV-2 and COVID-19: the most important research questions. Cell \& Bioscience, vol. 10, no. 1, pp. 40. http://dx.doi. org/10.1186/s13578-020-00404-4. PMid:32190290.

ZHOU, P., YANG, X.-L., WANG, X.-G., HU, B., ZHANG, L., ZHANG, W., SI, H.-R., ZHU, Y., LI, B., HUANG, C.-L., CHEN, H.-D., CHEN, J., LUO, Y., GUO, H., JIANG, R.-D., LIU, M.-Q., CHEN, Y., SHEN, X.-R., WANG, X., ZHENG, X.-S., ZHAO, K., CHEN, Q.-J., DENG, F., LIU, L.-L., YAN, B., ZHAN, F.-X., WANG, Y.-Y., XIAO, G.-F. and SHI, Z.-L., 2020. Discovery of a novel coronavirus associated with the recent pneumonia outbreak in humans and its potential bat origin. Nature, vol. 579, no. 7798, pp. 270-273. http://dx.doi. org/10.1038/s41586-020-2012-7. 